\title{
Disseminated gonococcal infection associated with deficiency of the second component of complement
}

\author{
P.H.M. McWhinney, P. Langhorne, W.C. Love and K. Whaley' \\ Department of Infection and Tropical Medicine, Ruchill Hospital, Glasgow G20 9NB and 'University of \\ Glasgow Department of Pathology, Western Infirmary, Glasgow G11 6NT, UK
}

\begin{abstract}
Summary: A case of $\mathbf{C 2}$ deficiency presenting with disseminated gonococcal infection is described. The predisposition of $\mathrm{C2}$-deficient individuals to infection in addition to the commoner problem of immune complex diseases is noted. Attention is drawn to the absence of documented cases of gonococcal infection associated with $\mathrm{C2}$ deficiency. No other homozygous C2 deficient family members were identified. Lifelong penicillin prophylaxis was recommended for the patient.
\end{abstract}

\section{Introduction}

Deficiency of the second component of complement (C2) is an autosomal recessive disorder often associated with systemic lupus erythematosus (SLE) like syndromes, ${ }^{1}$ but also frequently associated with recurrent sepsis. The most commonly implicated organisms are meningococci, pneumococci and Haemophilus influenzae. ${ }^{2}$ The association of terminal complement deficiency (particularly C8) with disseminated gonococcal infection (DGI) is well documented, ${ }^{3}$ but $\mathrm{C} 2$ deficiency has not been noted to be associated with gonococcaemia. We report a case of subcute gonococcal septicaemia associated with $\mathrm{C} 2$ deficiency.

\section{Case report}

A 22 year old single male presented with a 6 day history of sore throat and a migrating arthropathy of knees and wrists associated with a skin rash. While on holiday in Spain 2 months prior to admission he had a similar episode of self limiting arthropathy, associated with diarrhoea but no skin rash. He had mild asthma, and gave a history of an episode of bronchitis and two episodes of pleurisy. His only medications were a salbutamol inhaler and, just prior to admission, indomethacin. He had recent unprotected sexual contact with a known female partner, but denied any other contacts.

\footnotetext{
Correspondence: P.H.M. McWhinney, M.R.C.P., Department of Medical Microbiology, Royal Free Hospital, Hampstead, London NW3 2QG, UK Accepted: 16 October 1990
}

Apart from a single temperature spike of $38^{\circ} \mathrm{C}$ he remained apyrexial. He had marked painful limitation of movement in his wrists, knees and ankles but no synovial effusion. Sparse cutaneous lesions small erythematous macules, tiny pustules and crusted lesions - were noted. After admission a few more pustules developed. Otherwise examination was unremarkable. Routine biochemical and haematological investigations were normal except for an erythrocyte sedimentation rate of 49 and a C-reactive protein of $21 \mathrm{mg} / \mathrm{l}$ (normal range $<6$ ). His ASO titre was less than 200 Todd units. A throat swab grew group $\mathrm{C}$ beta haemolytic streptococci. No organisms were grown from the skin lesions. Blood cultures grew Neisseria gonorrhoeae serogroup WI (genetic serovar: Aedgkih, Pharmacia serovar: Arost), which was sensitive to less than $0.015 \mathrm{mg} / 1$ penicillin. Tests for antinuclear factor, rheumatoid factor, anti-Ro, anti-La, anti$\mathrm{Sm}$ and anti-RNP were all negative. Viral serological screens were negative as was serology for meningococci, yersinia, syphilis and Borrellia burgdorferi. Details of complement levels are shown in Table I.

He was treated with benzyl penicillin and made a rapid and complete recovery. There was no evidence of other sexually transmitted disease. His immediate family all have normal levels of $\mathrm{C} 2$. Lifelong prophylaxis with phenoxymethyl penicillin has been recommended.

\section{Discussion}

C2 deficiency appears to present most frequently with immune complex diseases. ${ }^{4}$ However, in a series of 38 cases of which 36 had presented with a connective tissue disorder, many had a history of 
Table I Complement levels

\begin{tabular}{lll}
\hline Component & Level & Normal range \\
\hline $\begin{array}{l}\text { CH50 } \\
\quad \text { alternative pathway }\end{array}$ & $0 \mathrm{U} / \mathrm{ml}$ & $150-250 \mathrm{U} / \mathrm{ml}$ \\
Haemolytic activity & $175 \mathrm{U} / \mathrm{ml}$ & $143-384 \mathrm{U} / \mathrm{ml}$ \\
Clq & $121 \%$ & $63-158 \%$ \\
Clr & $113 \%$ & $64-158 \%$ \\
C1s & $181 \%$ & $70-145 \%$ \\
$\mathrm{C} 2$ & $\mathrm{Undetectable}$ & $56-175 \%$ \\
$\mathrm{C} 3$ & $1.3 \mathrm{mg} / \mathrm{ml}$ & $0.72-1.8 \mathrm{mg} / \mathrm{ml}$ \\
$\mathrm{C} 4$ & $439 \mu \mathrm{g} / \mathrm{ml}$ & $199-574 \mu \mathrm{ml}$ \\
Cl inhibitor & $310 \mu \mathrm{g} / \mathrm{ml}$ & $160-370 \mu \mathrm{g} / \mathrm{ml}$ \\
Factor B & $148 \mu \mathrm{g} / \mathrm{ml}$ & $149-421 \mu \mathrm{g} / \mathrm{ml}$ \\
\hline
\end{tabular}

significant bacterial infections. ${ }^{1}$ In another series of 77 individuals with $\mathrm{C} 2$ deficiency, ${ }^{2} 32$ had had significant bacterial infections, including 11 individuals with pneumococcal sepsis on one or more occasion and 3 each of meningococci, $H$. influenzae and tuberculosis, but no cases of DGI. The absence of cases of DGI in both of these series and other published cases is striking, implying either that $\mathrm{C} 2$ deficiency does not predispose to gonococcal sepsis or that there has been a failure to diagnose C2 deficiency in infected patients. Alternatively, cases may not have been reported due to the mistaken assumption that the well documented association of $\mathrm{C} 2$ deficiency with neisserial sepsis includes DGI. As DGI is a less spectacular infection there may be a tendency for cases not to be investigated. It has also been suggested that as aerial transmission is important for meningococci they have greater opportunities for spread to susceptible individuals than gonococci. ${ }^{2}$ In view of the susceptibility of C2-deficient individuals to infections by capsulated bacteria it would be surprising if this case represented the coincidence of two independ ent conditions. Furthermore it has been shown that in vitro killing of $N$. gonorrhoeae is slowed when $\mathrm{C} 2 \mathrm{D}$ deficient plasma is used. ${ }^{5}$

The organism isolated in this case is a serum resistant strain typical of those associated with? DGI. ${ }^{6}$ Even these do not usually cause systemic disease, and individuals who develop DGI mayo have defective host defence mechanisms. Addi $\frac{\text { क }}{5}$ tionally gonococci not usually associated with dissemination may cause invasive disease in suchn patients. $^{7}$

C2 deficiency is the most common complemen $\vec{P}$ deficiency with a prevalence of $1: 10,000$. It has already been suggested that gonococcal septicaemia is an indication to screen for complemen $\vec{b}$ deficiencies, ${ }^{8}$ and this case adds further weight to. that suggestion. Measurement of the $\mathrm{CH} 50$ is convenient and readily available screening test which will prompt further investigation wheres appropriate. Diagnosis of the defect has importanĩ implications for the long term prophylaxis of individuals who are prone to infections (a sub을 group of $\mathrm{C} 2$ deficient individuals). ${ }^{9}$ As the most commonly diagnosed pathogen is $S$. pneumoniae oral penicillin is an appropriate antibiotic $\stackrel{\frac{\omega}{\omega}}{\frac{\omega}{2}}$ Pneumococcal vaccine may not be effective. The predisposition to infections may only become 80 parent when individuals (as in this case) are agedover 20 years, and family members should $\Phi_{\infty}$ screened, so primary prophylaxis may be offered where appropriate.

\section{Acknowledgement}

We are grateful to Dr R. Fallon, Department of Microbiology, Ruchill Hospital for his advice.

\section{References}

1. Angello, V. Complement deficiency states. Medicine (Baltimore) 1978, 57: 1-23.

2. Ross, S.C. \& Densen, P. Complement deficiency states and infection: epidemiology, pathology and consequences of neisserial and other infections in an immune deficiency. Medicine (Baltimore) 1984, 63: 243-273.

3. Petersen, B.H., Terence, T.J., Snyderman, R. \& Brooks, G.F. Neisseria meningitidis and $N$. gonorrhoeae bacteremia associated with C6, C7 or C8 deficiency. Ann Inton Med 1979, 90: $917-920$.

4. Schifferli, J.A. \& Peters, D.K. Complement, the immunecomplex lattice, and the pathophysiology of complement deficiency syndromes. Lancet 1983, ii: 957-959.

5. Densen, P., McRill, C. \& Ross, S.C. The contribution of alternate and classical complement pathways to gonococcal killing and C3 fixation. In: Poolman, J.T. (ed.) Gonococci and Meningococci. Kluwer Academic Publishers, Dordrecht, 1988, pp. $693-697$.
6. Editorial. Disseminated gonococcal infection. Lancet, 1984, if 832-833.

7. Forster, G.E., Pinching, A.J., Ison, C.A., Easmon, C.S.F. \& Munday, P.E. New microbial and host factors in disseminated gonococcal infection: case report. Genitourin Med 1987, 63. D 169-171.

8. Ellison, R.T., Curd, J.G., Kohler, P.F., Reller, L.B. \& Juckson, F.N. Underlying complement deficiency in patients with disseminated gonococcal infection. Sex Transm Dis 1987, 14: $201-204$.

9. Densen, P. Complement. In: Mandell, G.L., Douglas, R.G.N Bennett, J.E. (eds) Principles and Practice of Infectious Diseases. Churchill Livingstone, New York, 1990, pp. 62-81주 